\title{
Effectiveness of the low-level laser therapy in the management of bisphosphonate- induced osteonecrosis of the jaws: A case report
}

\author{
Eficácia do laser de baixa intensidade no tratamento da osteonecrose dos maxilares induzida por \\ bisfosfonatos: Relato de caso
}

Eficacia del láser de baja intensidad en el tratamiento de la osteonecrosis de los maxilares inducida por bisfosfonatos: Reporte de caso

Lucas Geazi da Silva Souza

ORCID: https://orcid.org/0000-0003-4932-3241 Centro Universitário Braz Cubas, Brazil

E-mail: Geazilucas612@gmail.com

Luana Domingos de Oliveira

ORCID: https://orcid.org/0000-0002-2767-879X

Centro Universitário Braz Cubas, Brazil

E-mail: Luana.doliveira@ hotmail.com

Gabriel Pereira Nunes

ORCID: https://orcid.org/0000-0001-7001-967X Universidade Estadual Paulista Júlio de Mesquita Filho, Brazil

E-mail: Gabriel.pereira.nunes@ hotmail.com

Laila dos Santos Cividanes

ORCID: https://orcid.org//0000-0003-4986-614X Centro Universitário Braz Cubas, Brazil E-mail: Laila_cividanes@hotmail.com

Cristian Michael Dahan

ORCID: https://orcid.org/0000-0002-6057-1265 Centro Universitário Braz Cubas, Brazil E-mail: Cristian_dahan@hotmail.com.br

Andressa Kleyslla Guedes Pereira ORCID: https://orcid.org/0000-0003-2290-3879 Centro Universitário Braz Cubas, Brazil

E-mail: Andressavestibular012@gmail.com

Dárcio Kitakawa

ORCID: https://orcid.org/0000-0002-4321-5306 Centro Universitário Braz Cubas, Brazil E-mail: dkitakawa@yahoo.com

Viviana Moraes Neder

ORCID: https://orcid.org/0000-0001-9594-1054 Centro Universitário Braz Cubas, Brazil

E-mail: Nederviviana@gmail.com

Luis Felipe das Chagas e Silva de Carvalho ORCID: https://orcid.org/0000-0003-1063-4624 Centro Universitário Braz Cubas, Brazil Universidade de Taubaté, Brazil E-mail: luisfelipecarvalho@hotmail.com

\begin{abstract}
The aim of this study was to report a clinical case of osteonecrosis caused by bisphosphonates and its treatment with the aid of laser therapy. Low-level laser therapy (LLLT) is a resource used that is characterized by photobiostimulation and photobiomodulation, promoting analgesia and anti-inflammatory effects and can also be a tool for treating osteonecrosis induced by bisphosphonates (BFs), when associated also to drug therapy. The present case is a 63-yearold patient, leukoderma, with thyroid disorder and osteoporosis, making continuous use of medicaments classified as BF's. He had a dental fracture and sensitivity to cold and treatment started with prophylaxis. After radiography of the dental elements, restorations were performed and tooth extraction (element 46). In the postoperative period, the patient reports pain and a bone exposure were observed clinically in the region of the extracted area, with osteonecrosis being diagnosed. Drug therapy was promptly applied and the use of LLLT was chosen as an adjunctive and supportive therapy. It is plausible to infer the need for attention to patients undergoing drug treatment with bisphosphonates, fully evaluating
\end{abstract}


the best treatment for the possible occurrence of osteonecrosis in view of LLT as an effective complementary therapeutic approach.

Keywords: Osteonecrosis; Bisphosphonates; Laser therapy; Treatment.

\begin{abstract}
Resumo
O objetivo deste estudo foi relatar um caso clínico de osteonecrose causada por bisfosfonatos e seu tratamento com o auxílio de laserterapia. A terapia com laser de baixa intensidade (LLLT) é um recurso utilizado que se caracteriza pela fotobioestimulação e fotobiomodulação, promovendo analgesia e efeitos anti-inflamatórios podendo também ser uma ferramenta de manejo da osteonecrose induzida pelo uso de Bisfosfonatos (BFs), quando associada também à terapia medicamentosa. O presente caso trata-se de uma paciente de 63 anos, leucoderma, com distúrbio da tireoide e osteoporose, fazendo uso contínuo de medicamentos classificados como BF's. Apresentava fratura dentária e sensibilidade ao frio e o tratamento iniciou com uma profilaxia. Após a radiografia dos elementos dentários, foram realizadas restaurações e uma exodontia do dente 46 . No pós-operatório paciente relata dor e foi observado clinicamente uma exposição óssea na região do dentre extraído, sendo diagnosticada a osteonecrose. Prontamente aplicou-se terapia medicamentosa e se optou pelo uso de LLLT como terapia coadjuvante e auxiliadora no tratamento. É plausível inferir a necessidade de atenção a pacientes que fazem tratamento medicamentoso com bisfosfonatos, avaliando de forma completa o melhor tratamento para a possível ocorrência de osteonecrose dos maxilares tendo em vista a LLT como uma conduta terapêutica complementar eficaz.
\end{abstract}

Palavras-chave: Osteonecrose dos maxilares; Bisfosfonatos; Laserterapia de baixa intensidade; Tratamento.

\title{
Resumen
}

El objetivo de este estudio fue reportar un caso clínico de osteonecrosis por bifosfonatos y su tratamiento con la ayuda de la terapia a láser. La terapia con láser de baja intensidad (LLLT) es un recurso utilizado que se caracteriza por la fotobioestimulación y fotobiomodulación, promoviendo efectos analgésicos y antiinflamatorios y puede ser también una herramienta para el tratamiento de la osteonecrosis inducida por el uso de bisfosfonatos (BFs), cuando se asocia también a terapia de medicamentos. El presente caso trata de un paciente de 63 años, leucodermia, con trastorno tiroideo y osteoporosis, que hace uso continuo de fármacos clasificados como LM. Tenía una fractura dentaria y sensibilidad al frío y el tratamiento se inició con profilaxis. Luego de la radiografía de los elementos dentarios, se realizaron restauraciones y extracción del elemento 46. En el postoperatorio el paciente refiere dolor y se observó clínicamente una exposición ósea en la región del área extraída, con diagnóstico de osteonecrosis. La terapia con medicamentos se aplicó rápidamente y se eligió el uso de LLLT como terapia complementaria y de apoyo. Es plausible inferir la necesidad de atención a los pacientes en tratamiento farmacológico con bifosfonatos, evaluando a fondo el mejor tratamiento para la posible aparición de osteonecrosis de los maxilares en vista del LLT como un eficaz abordaje terapéutico complementario.

Palabras clave: Osteonecrosis de los maxilares; Bisfosfonatos; Terapia con láser de baja intensidad; Tratamiento.

\section{Introduction}

Bisphosphonates (BFs) are a class of potent drugs used since 1960 for the treatment of osteoporosis, malignant neoplasms of bone metastases and diseases of bone metabolism, whose function is to inhibit the activity of osteoclasts, that is, to prevent bone resorption (Aragon-Ching et al., 2009; Brozoski et al., 2012; Cremers et al., 2019; de Medeiros et al., 2017).

Thus, its therapeutic use has increased a lot lately to treat pathogens such as Paget's disease, malignant hypercalcemia, osteoporosis and metastatic and osteolytic disease. (Khan et al., 2016; Favus et al., 2010; Lee et al., 2005). However, this medicament class can develop adverse effects, and in dentistry, maxillomandibular osteonecrosis stands out, being a lesion that is not reversible, having the tissue bone not remodeled and the bone necrotic, this due to the lack of blood irrigation to the bones (Luke et al., 2019; Ervolino et al., 2019; Mauceri et al., 2018; Rogers et al., 2013).

When a patient is diagnosed with maxillomandibular osteonecrosis, all the tissue that is necrotic and infected should be removed and thus proceeded with an appropriate treatment protocol. Therefore, as an alternative, low-level laser therapy (LLLT) together with drug therapy has been effective in treating this condition, as soon as this therapeutic option proposes analgesic and anti-inflammatory action, being painless, little invasive, stimulates the increase in the synthesis of fibroblasts and the increase of osteoblastic activity, thus improving healing to bone tissue (Sedghizadeh et al., 2021; Torres et al., 2020; Weber et al., 2016).

The elementary working underlying LLLT has not totally been clarified yet. The initial actions happen at the mitochondrial level, principally in the electron transport chain, where there is the process of activating photoreceptors 
through irradiation, which promotes an increase in the capacity of cellular energy. Other responses accentuate the proliferation and differentiation of cells when they happen, including the transduction of signals at the cytoplasmic level (Sedghizadeh et al., 2021; Torres et al., 2020).

Clinical studies (Sanchez et al., 2020; Mauceri et al., 2018) showed a higher therapeutic success indexes when LLLT was combined with conventional treatment in the management of medication-related maxillomandibular osteonecrosis. Corroborating these findings, other studies also mentioned the benefits of the inclusion of LLLT as an encouraging election for medication-related maxillomandibular osteonecrosis treatment. Therefore, this study aimed to evaluate the effect of the lowlevel laser therapy, as a treatment strategy for bisphosphonate-induced osteonecrosis of the jaws (BIOJ) through the presentation of a case.

\section{Methodology}

This present article corresponds to a case report that qualifies as a descriptive and qualitative study (Nunes et al., 2021), where it addresses the manifestation of maxillary-mandibular osteonecrosis, as well as its treatment with LLLT. In addition, it describes how direct research collects data and information related to the study through access to medical records and exams, with the researcher being the primary instrument (Pereira et al., 2018; Cândido et al., 2021). The Informed Consent Form was signed by the patient before the treatment was carried out, authorizing the treatment to be carried out, as well as the use of images and documentation. The ethical principles of the Declaration of Helsinki were respected. To elucidate the entire treatment proposed, images were used and as a complement to the study, a literature review was carried out through articles from the Scielo, PubMed and BIREME databases.

\section{Case Presentation}

A 63-year-old female patient, white, presented at the clinical division of School of Dentistry, of the Centro Universitário Braz Cubas, with a major complaint of fractured teeth and sensitivity to coldTherefore, in the anamnesis, the patient reported having a thyroid disorder and osteoporosis, being treated with the drugs Levotrixin, Risedronate and Ibandronate. Thus, the treatment started with prophylaxis of the buccal cavity, then radiographic examination of the dental elements 15, 46, 25 and 27 was performed. Subsequently, class V restorations of teeth (15 and 16) and tooth extraction (16) were fullfied. Postoperatively, the patient reported painful symptoms, which was soon observed in the clinical examination, a bone exposure by lingual in the region of tooth 46. Soon afterwards, with the patient's history, radiographic examination and clinical examination, maxillarymandibular osteonecrosis was diagnosed (Figure 1). 
Figure 1 - Intraoral aspect of osteonecrosis induced by BFs in the region of the inferior first molar.

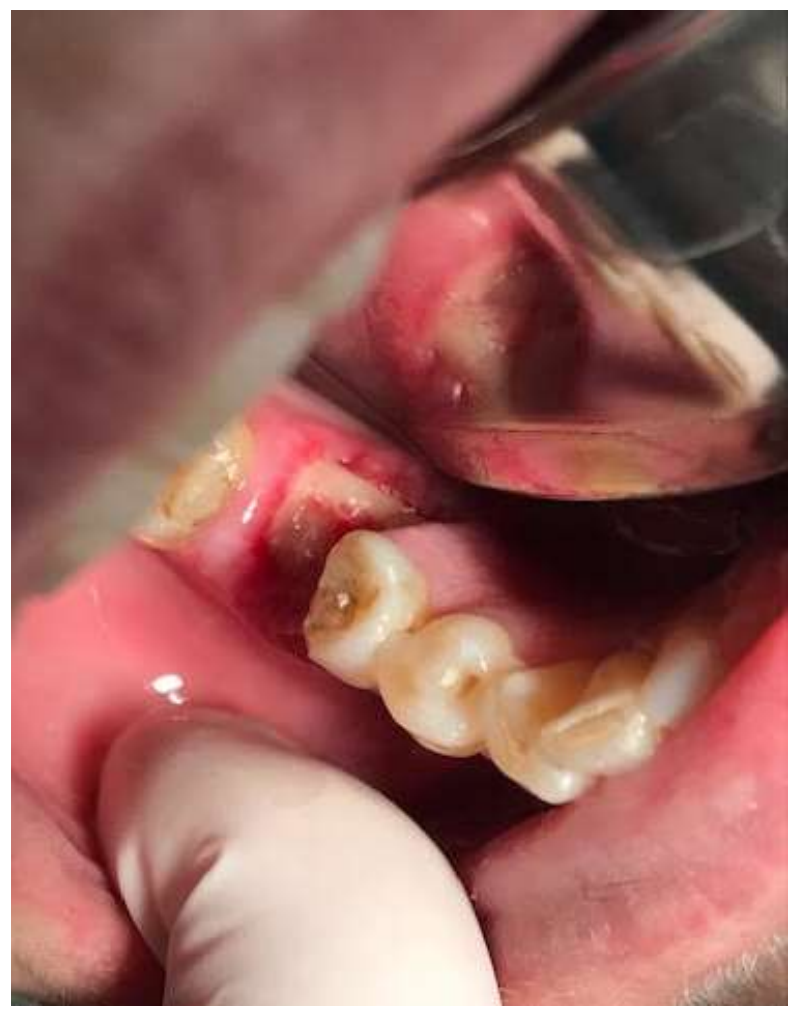

Source: Authors.

It presents with necrotic bone exposure, with loss of continuity of the oral mucosa, the region stands out in an erythematous form and with loss of spongy trabeculation and bone density. Moreover, it manifests with a slow healing process.

The treatment consisted of debridement therapy, antibiotic administration, and multiple LLLT sessions: drug therapy with analgesic and systemic antibiotic, clindamycin 300mg, compressed, orally, for $6 / 6$ hours for a period of 15 days was used, as well as debridement with the introduction of surgical cement. Two days after the operation, bone necrosis was monitored, where bone exposure was still observed, although asymptomatic. Thus, the region was cleaned and the patient was asked to rinse with $0.2 \%$ chlorhexidine.

In view of the fact, it was opted to use the low-level laser therapy treatment in conjunction with antibiotic therapy. In total, six laser therapy sessions were held (Figure 2.). The first session took place in an expected manner, without the presence of pain and with the epithelium undergoing a favorable formation process. In the second session a great evolution was noted: absence of pain and epithelium in a favorable process of formation and with satisfactory healing. The patient continued to rinse with $0.2 \%$ chlorhexidine. In the other sessions, good evolution and improvement in healing were also noted. Thus, after the sixth and last session, it was possible to observe complete healing of the region, thus concluding the proposed treatment (Figure 3). 
Figure 2 - Evolution of the case from diagnosis to the end of treatment with medications and LLLT. A - Diagnosis of mandibular osteonecrosis; B $-1^{\text {st }}$ session of LLLT; C $-2^{\text {nd }}$ session; D $-3^{\text {rd }}$ session; $\mathrm{E}-4^{\text {th }}$ session; F - Result of treatment after the $5^{\text {th }}$ and last session $\left(6^{\text {th }}\right)$ of laser therapy.

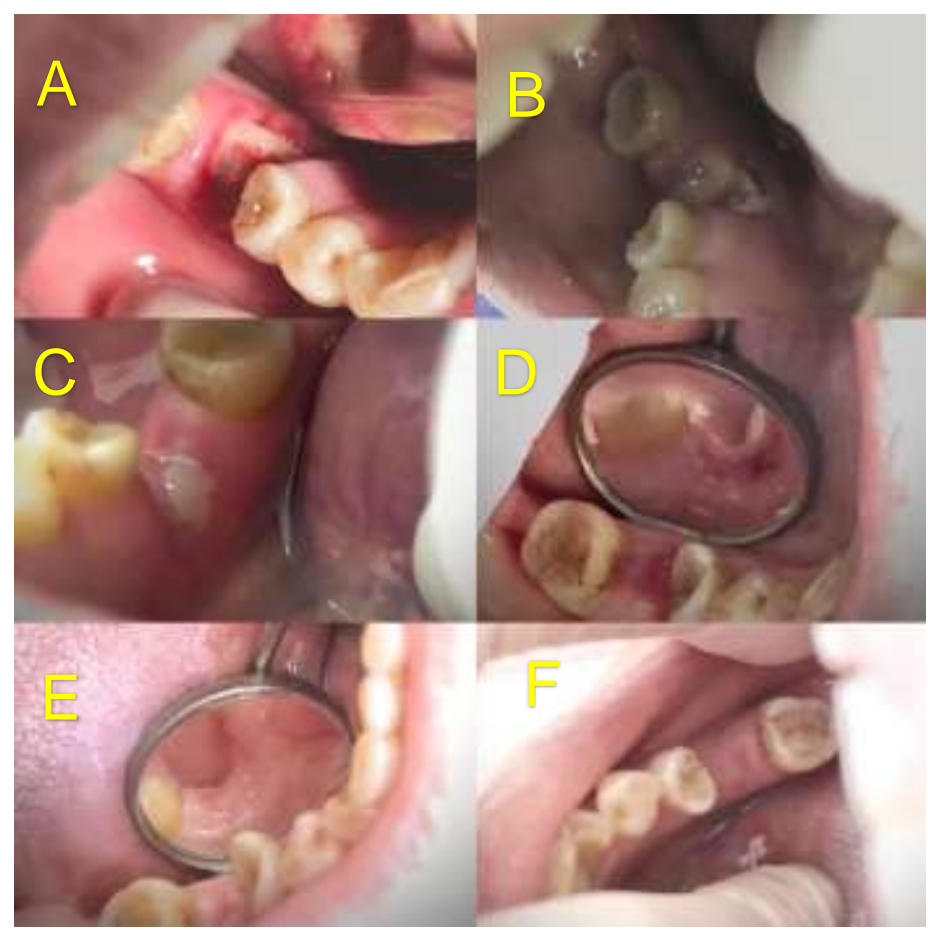

Source: Authors.

Figure 3 - Final intraoral aspect of BFs-induced osteonecrosis in the inferior first molar region after low-level laser therapy.

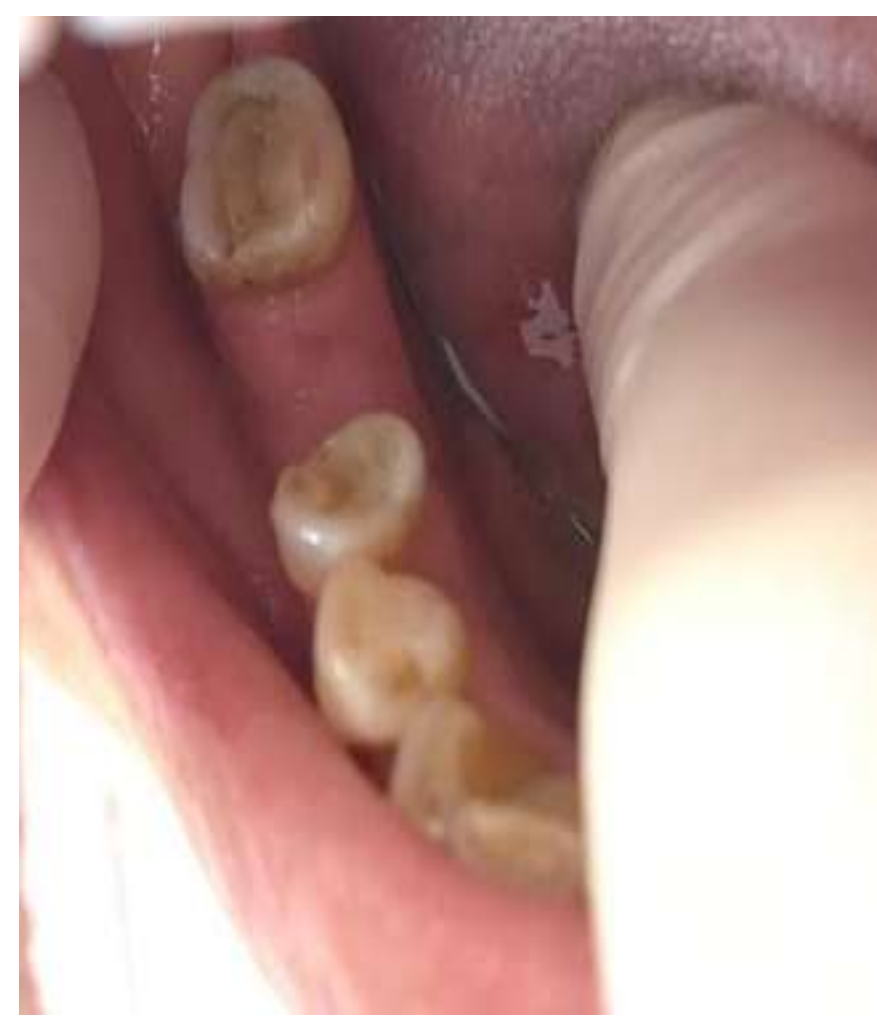

Source: Authors. 
The tissue presents itself in a healthy way with well-defined healing and regeneration. Furthermore, it highlights the oral mucosa of the recovered region and with a pink color, being of normal appearance.

\section{Discussion}

Bisphosphonate-induced maxillomandibular osteonecrosis has become a major preoccupation in oral medicine and dentistry due to the trouble treatment and obtaining a cure, considerably compromising the life quality of the diseased. The relationship between the continuous use of a drug class called BFs is presented as the main cause, which, according to Torres et al. (2020), cited by Brozoski et al. (2012), are used for the treatment of bone metastases, lung cancer, multiple myeloma, Paget's disease, disease control of calcium metabolism and others.

For Cremers et al. (2019) maxillary-mandibular osteonecrosis affects the jaw or maxilla bone and may appear painful or asymptomatic for weeks, months or years. It can be diagnosed through anamnesis and clinical examination based on the signs and symptoms presented by the patient. That said, Ruggiero et al (2014) also states that the clinical characteristics for a diagnosis include a slow healing process, with necrotic intraoral bone exposure, with loss of continuity of the oral mucosa, erythematous aspect, ulcerations, in addition to drainage secretion and fistula on the skin or mucosa. Emphasizing that the lesions resulting from bone necrosis can appear spontaneously or through some surgical intervention, for example, the extraction of some dental element.

In addition, Luke et al. (2019) described that through radiographic examination it is possible to observe an ill-defined osteolytic area, with destruction of the cortex and loss of spongy trabeculation and bone density, which can even cause pathological fractures. According to Weber et al. (2016) one of the promising technologies for the treatment of BIOJ is LLLT. This treatment method is simple and associated with antibiotic therapy that promotes healing and regeneration of necrotic tissue. For this purpose, a type of photosensitizing agent is applied and then the application of the red laser. With that, this combination will generate oxygen, in which it will eliminate bacteria present there. It then achieves better tissue healing.

In this way, the laser acts directly on the cells, activating some components and from there results in biochemical reactions, which are responsible for altering the cellular metabolism and achieving its proper goal of healing and regeneration of healthy tissue. LLLT is skillful to modulate the metabolism of osteoblasts cells by increasing their multiplication and differentiation (Sedghizadeh et al., 2021; Torres et al., 2020). Moreover, LLLT is claimed to have beneficial anti-inflammatory and analgesic actions (Weber et al., 2016). It stimulates bone deposition and soft tissue healing and has important angiogenic properties for bone repair. Positive results, which have been pointed and confirmed with a meta-analysis, include an improve and increase in collagen synthesis and tensile strength, favoring the resolution of the inflammatory activity and promotes healing and wound size (Enwemeka et al., 2004).

In this case report, was used the laser emitting GaAlAs at a wavelength of $808 \mathrm{~nm}$, energy density of $19.4 \mathrm{~J} / \mathrm{cm}^{2} / \mathrm{point}$ (8 points) for a period of 2 months (6 sessions/applications). Other regimens have been reported for the management of BIOJ. Romeo et al. (2011) utilized a double diode laser (GaAs) concomitantly emitting at 2 different wavelengths, $650 \mathrm{~nm}$ and $904-$ $910 \mathrm{~nm}$. In addition, Vescovi et al. (2014) made applications a LLLT with precedent irrigations with a 10\% povidone iodine solution and an emitter Nd: YAG laser at a wavelength of $1064 \mathrm{~nm}$, power of $2.25 \mathrm{~W}$ and frequency of $15 \mathrm{~Hz}$ in an unfocused mode and $2 \mathrm{~mm}$ away from the tissues for 60 seconds (power density, $1562.5 \mathrm{~W} / \mathrm{cm}^{2}$, fluence, $7 \mathrm{~J} / \mathrm{cm}^{2}$ ) 5 times repeatedly. Altay et al. (2014) used a GaAlAs device with a wavelength of $808 \mathrm{~nm}$, power of $0.5 \mathrm{~W}$, and an energy density of $5 \mathrm{~J} / \mathrm{cm}^{2}$. Regarding to the amount and frequency of LLLT applications, there was a variation in the studies from one (Vescovi et al., 2014) to 5 applications (Altay et al., 2014) and from 650 (Romeo et al., 2011) to $1562.5 \mathrm{~nm}$ (Vescovi et al., 2014) respectively. It is 
noteworthy that the protocols mentioned displayed good results, as did this present case by improving tissue repair (Altay et al., 2014), complete mucosal healing in about 2 weeks (Vescovi et al., 2014) and a decrease of pain (Romeo et al., 2011).

It is speculated the strategy to curing BIOJ is to control microorganisms (Bacteria) and eradication the necrotic tissue, but above all favor biostimulation the region, which was reached by complementary treatment with LLLT.

\section{Final Considerations}

Therefore, it can be inferred that patients with the metabolic condition of osteoporosis and cancer, who are being treated by bisphosphonates will be subject to trigger osteonecrosis of the jaws. It is therefore important that when a professional comes across patients who use this class of drugs (BFs), always highlight a suspicious degree.

Thus, BIOJ is a complex and debilitating condition, therefore, several treatment approaches have been discussed in the literature. In the case report in question, the LLLT showed promise, since the applied approach brought satisfactory results since the second session of laser therapy, where the epithelium was in a favorable process of formation and with good healing. This therapeutic intervention favors the stimulation of cellular activity, and also promotes an anti-inflammatory, analgesic and healing effect.

Based on the results obtained from this clinical case report and considering its limitations, concluded that the association LLLT and conventional treatment was effective in the treatment of BIOJ, which is put forth as a promising choice for complementary use in the therapy of this pathological alteration. Nevertheless, is recommended that more studies must be conducted to prove the beneficial effects and effectiveness of LLLT as an adjunctive therapy in the therapy of BIOJ.

\section{References}

Altay, M., A., Tasar, F., Tosun, E., Kan, B. (2014) Low-level laser therapy supported surgical treatment of bisphosphonate related osteonecrosis of jaws: a retrospective analysis of 11 cases. Photomed Laser Surg. 32(8):468-75.

Aragon-Ching, J. B., Ning, Y. M., Chen, C. C., Latham, L., Guadagnini, J. P., Gulley, J. L., Arlen, P. M., Wright, J. J., Parnes, H., Figg, W. D., \& Dahut, W. L. (2009). Higher incidence of Osteonecrosis of the Jaw (ONJ) in patients with metastatic castration resistant prostate cancer treated with anti-angiogenic agents. Cancer investigation, 27(2), 221-226.

Brozoski, M. A., Traina, A, A, Deboni, M. C. Z., Marques, M. M., \& Naclério-Homem, M. G. (2012). Osteonecrose maxilar associada ao uso de bisfosfonatos. Revista Brasileira de Reumatologia, 52(2), 265-270.

Cândido, E.L., Ribeiro, T. R.G., Brito, M.A.F., Rodrigues, S.B., Feitosa, M.D.S., Feitosa, F.P.J., \& Freitas, J.F. (2021). Aspectos éticos e trâmites da publicação de relato de caso no Brasil. Research, Socity and Development, 10 (2), 1-5.

Cremers, S., Drake, M. T., Ebetino, F. H., Bilezikian, J. P., \& Russell, R. (2019). Pharmacology of bisphosphonates. British journal of clinical pharmacology, $85(6), 1052-1062$.

de Medeiros, M. L., Araújo-Filho, I., da Silva, E. M., de Sousa Queiroz, W. S., Soares, C. D., de Carvalho, M. G., \& Maciel, M. A. (2017). Effect of low-level laser therapy on angiogenesis and matrix metalloproteinase-2 immunoexpression in wound repair. Lasers in medical science, 32(1), 35-43.

Enwemeka, C., S., Parker, J., C., Dowdy D., S., Harkness, E., E., Sanford L., E., Woodruff L., D. (2004) The efficacy of low-power lasers in tissue repair and pain control: a meta-analysis study. Photomed Laser Surg. 22(4):323-9.

Ervolino, E., Statkievicz, C., Toro, L. F., de Mello-Neto, J. M., Cavazana, T. P., Issa, J., Dornelles, R., de Almeida, J. M., Nagata, M., Okamoto, R., Casatti, C. A., Garcia, V. G., \& Theodoro, L. H. (2019). Antimicrobial photodynamic therapy improves the alveolar repair process and prevents the occurrence of osteonecrosis of the jaws after tooth extraction in senile rats treated with zoledronate. Bone, 120, 101-113.

Favus MJ. Bisphosphonates for osteoporosis. N Engl J Med. 363(21):2027-35.

Hellstein, J. W., \& Marek, C. L. (2005). Bisphosphonate osteochemonecrosis (bis-phossy jaw): is this phossy jaw of the 21st century? Journal of oral and maxillofacial surgery: official journal of the American Association of Oral and Maxillofacial Surgeons, 63(5), 682-689.

Khan, A., Morrison, A., Cheung, A., Hashem, W., \& Compston, J. (2016). Osteonecrosis of the jaw (ONJ): diagnosis and management in 2015. Osteoporosis international: a journal established as result of cooperation between the European Foundation for Osteoporosis and the National Osteoporosis Foundation of the USA, 27(3), 853-859.

Lee J. Y., Kim I. R., Park B. S., Kim Y. D., Chung I. K., Song J. M., \&Shin S. H. (2005). Effect of low-level laser therapy on oral keratinocytes exposed to bisphosphonate. Lasers Med Sci, 30(2), 635-43. 
Research, Society and Development, v. 10, n. 6, e17510615199, 2021

(CC BY 4.0) | ISSN 2525-3409 | DOI: http://dx.doi.org/10.33448/rsd-v10i6.15199

Luke, A. M., Mathew, S., Altawash, M. M., \& Madan, B. M. (2019). Lasers: A Review with their applications in oral medicine. Journal of lasers in medical sciences, 10(4), 324-329.

Madrid, C., \& Sanz, M. (2009). What impact do systemically administrated bisphosphonates have on oral implant therapy? A systematic review. Clinical oral implants research, 20 Suppl 4, 87-95.

Mauceri, R., Panzarella, V., Maniscalco, L., Bedogni, A., Licata, M. E., Albanese, A., \& Campisi, G. (2018). Conservative Surgical Treatment of Bisphosphonate-Related Osteonecrosis of the Jaw with Er,Cr:YSGG Laser and Platelet-Rich Plasma: A Longitudinal Study. BioMed Research International, $2018,1-10$

Neves, M., Gano, L., Pereira, N., Costa, M. C., Costa, M. R., Chandia, M., Rosado, M., \& Fausto, R. (2002). Synthesis, characterization and biodistribution of bisphosphonates Sm-153 complexes: correlation with molecular modeling interaction studies. Nuclear medicine and biology, 29(3), 329-338.

Nunes, T. P., Nunes, L. P., Silva, A. N. A., Pirovani, B. O., Morábito, M. J. S. D., de Morais, L.A., Gruba, A. S., \& Nunes, G. P. (2021). Effects adverse of treatment with selective inhibitors of serotonin recaptation on the fetus and neonatals of mothers with gestational depression: A critical review. Research, Society and Development, 10(4), e11210413937.

Pereira, AS et al. (2018). Metodologia da pesquisa científica. UFSM.

Reid, I. R., Bolland, M. J., \& Grey, A. B. (2007). Is bisphosphonate-associated osteonecrosis of the jaw caused by soft tissue toxicity? Bone, 41(3), 318-320. Rodriguez, A. C., Silva, C. E. X. S. R., Costa, D. M., Martins, M., Oliveira, V., Neto, R. M. S., ... Chavantes, M. C. (2019). Low level laser therapy as coadjuvant in bisphosphonate related osteonecrosis of the jaws: a pilot study. International Journal of Oral and Maxillofacial Surgery, 48, 103

Rogers M. J. (2003). New insights into the molecular mechanisms of action of bisphosphonates. Current pharmaceutical design, 9(32), $2643-2658$.

Romeo, U., Galanakis, A., Marias, C., Vecchio, A. D., Tenore, G., Palaia, G., Vescovi, P., \& Polimeni, A. (2011). Observation of pain control in patients with bisphosphonate-induced osteonecrosis using low level laser therapy: preliminary results. Photomedicine and laser surgery, 29(7), 447-452.

Ruggiero, S. L., Dodson, T. B., Fantasia, J., Goodday, R., Aghaloo, T., Mehrotra, B., O'Ryan, F., \& American Association of Oral and Maxillofacial Surgeons (2014). American Association of Oral and Maxillofacial Surgeons position paper on medication-related osteonecrosis of the jaw--2014 update. Journal of oral and maxillofacial surgery: official journal of the American Association of Oral and Maxillofacial Surgeons, 72(10), 1938-1956.

Sánchez, M., D., P., R., Statkievicz, C., de Mello-Neto, J. M., Toro, L. F., Bassi, A., Garcia, V. G., Theodoro, L. H., \& Ervolino, E. (2020). The Effectiveness of the Low-Level Laser, Antibiotic and Surgical Therapy in the Treatment of Medication-Related Osteonecrosis of the Jaws: A Case Report. Journal of lasers in medical sciences, 11(1), 98-103.

Sedghizadeh, P. P., Sun, S., Jones, A. C., Sodagar, E., Cherian, P., Chen, C., Junka, A. F., Neighbors, J. D., McKenna, C. E., Russell, R., \& Ebetino, F. H. (2021). Bisphosphonates in dentistry: Historical perspectives, adverse effects, and novel applications. Bone, 147, 115933. Advance online publication.

Torres, A. A., de Freitas, B. L., Carneiro, P. P., de Sousa, A., Arêa Leão Ferraz, M. Â., de Pinho Mendes, J., Costa, A., \& Pinto, A. (2020). Medication-Related Osteonecrosis of the Jaw and Low-Level Laser Therapy as Adjuvant Treatment: A Case Report. Journal of lasers in medical sciences, 11(4), 497-499.

Vescovi, P., Merigo, E., Meleti, M., Manfredi, M., Fornaini, C., Nammour, S., et al. (2014). Conservative surgical management of stage I bisphosphonate-related osteonecrosis of the jaw. Int J Dent. 2014

Weber, J. B., Camilotti, R. S., \& Ponte, M. E. (2016). Efficacy of laser therapy in the management of bisphosphonate-related osteonecrosis of the jaw (BRONJ): a systematic review. Lasers in medical science, 31(6), 1261-1272. 